\title{
ANTIBIOGRAM PROFILING OF HELICOBACTER PYLORI STRAINS AND THE EFFICACY OF BRASSICA CAPITATA AGAINST RESISTANT STRAINS ISOLATED FROM THE PATIENTS SUFFERING FROM GASTRODUODENAL DISEASES IN GUWAHATI, ASSAM
}

\author{
SHWETA MAHANT ${ }^{1}$, VALENTINA GEHLOT ${ }^{1}$, SEEMA BHATNAGAR ${ }^{1}$, MEGHA RIKHI ${ }^{1}$, \\ ASISH KUMAR MUKHOPADHYAY ${ }^{2}$, SANGITANJAN DUTTA ${ }^{3}$, ANIL AGARWAL ${ }^{3}$, KUNAL DAS ${ }^{4}$, RAJASHREE DAS ${ }^{1 *}$
}

${ }^{1}$ Amity Institute of Biotechnology, Amity University, Noida - 201 303, Uttar Pradesh, India. ${ }^{2}$ Department of Bacteriology, National Institutes of Cholera and Enteric Disease, Kolkata, West Bengal, India. ${ }^{3}$ Department of Gastroenterology, Guwahati Medical Collages, Guwahati - 781 024, Assam, India. ${ }^{4}$ Department of Gastroentrology and Hepatology, Max Super Speciality Hospital, Vaishali, Ghaziabad, Uttar Pradesh, India. Email: rajashreepatra79@yahoo.co.in

Received: 09 February 2018, Revised and Accepted: 24 April 2018

\section{ABSTRACT}

Objective: Helicobacter pylori resistance toward commonly used antibiotics is increasing leading to the treatment failure; hence, our aim is to determine the antibiogram susceptibility pattern of $H$. pylori strains isolated from Guwahati, Assam (Northeast India) and also to test the efficacy of the Brassica capitata against the multi and dual drug-resistant strains of North and Northeast India.

Methods: Minimum inhibitory concentration of different antibiotics was determined by agar dilution method. Disc diffusion method was used to check the efficacy of B. capitata against clarithromycin (CLR), metronidazole (MTZ), and levofloxacin (LEV)-resistant H. pylori strains.

Results: All the $\mathrm{H}$. pylori strains were $100 \%$ sensitive to CLR, tetracycline, amoxicillin, and furazolidone. $72.8 \%$ of the strains were sensitive toward MTZ and 54.5\% were sensitive toward LEV. B. capitata showed good efficacy against the resistant strains of $H$. pylori of North and Northeast India.

Conclusion: Most of the H. pylori strains from Northeast India were sensitive toward the commonly used antibiotics for the treatment regime. B. capitata is effective against $H$. pylori infection, suggesting its potential as an alternative therapy, and opens the way for further studies on identification of novel antimicrobial targets of B. capitata.

Keywords: Helicobacter pylori, Antibiotic resistance, Brassica capitata.

(C) 2018The Authors. Published by Innovare Academic Sciences Pvt Ltd. This is an open accessarticle under the CC BY license (http://creativecommons. org/licenses/by/4. 0/) DOI: http://dx.doi.org/10.22159/ajpcr.2018.v11i8.25220

\section{INTRODUCTION}

Helicobacter pylori is a Gram-negative microaerophilic gastric pathogen causing various gastroduodenal (GI) diseases such as gastritis, peptic ulcer, mucosa-associated lymphoid tissue lymphoma, and gastric cancer. It is classified as Class I carcinogen by IARC in 1994 [1]. Its infection is present in more than half of the population worldwide [1-5] and to almost $80 \%$ of the Indian population [6]. Indian population is an amazing combination of diverse races and cultures; thus, its inhabitants also differ in their genetic traits. Till date, it was believed that dietary factors are responsible for high prevalence of such GI diseases in the Northeast region of India because of its geographically, culturally, and ethnically divergent population [7]. H. pylori-associated various GI diseases can be cured by proper eradication therapy which includes proton-pump inhibitor-based triple therapy with multiple antibiotics. The commonly used antibiotics are clarithromycin (CLR), amoxicillin (AMX), metronidazole (MTZ), furazolidone (FZ), tetracycline (TET), and levofloxacin (LEV) [8,9]. Use of the antibacterial agents in general population for curing the various respiratory and anaerobic infections has resulted in the emergence of antibiotic-resistant strains of $\mathrm{H}$. pylori which is the prime cause of treatment failure. Resistance to various antibiotics such as MTZ (10$90 \%)$, CLR $(0-15 \%)$, FZ (0-13\%), TET (1-2\%), and AMX (0-1\%) has been shown to be variable and dissimilar in various regions within the countries [10-14]. The prevalence of dual resistance and multidrug resistance has increased significantly in many countries and has become a major obstacle in eradicating the $H$. pylori infection [15]. For these reasons, the natural products can be an alternative to the commonly used drugs for the eradication of $H$. pylori.
Nature is a rich source of numerous natural resources which can have the beneficial effects such as anti-inflammatory, antidiabetic, and antioxidative [16]. It was observed and confirmed that diet rich in vegetables and fruits reduced the risk of having several chronic disorders and immune diseases. Brassica capitata (cabbage) is considered to be one of the natural gifts that are herbaceous and leafy plant belonging to the family of Brassicaceae, having anti-inflammatory property and is generally used in cooking $[17,18]$.

Against this background, the present study has been conducted (1) to study the antimicrobial susceptibility pattern of $H$. pylori strains from Northeast India and (2) to evaluate the efficacy of B. capitata as an antimicrobial agent against the multi and dual drug-resistant strains of H. pylori isolates from North and Northeast India.

\section{METHODS}

Patients and specimens

A total of 98 biopsies were collected from the patients having an average age of 42.6 years and M:F ratio of 1:0.46 visiting Gauhati Medical College, Guwahati, Assam, with clinical symptoms of gastrointestinal disorders and underwent endoscopy. Samples were collected as per the inclusion and exclusion criterion.

\section{An inclusion criterion includes}

Patients aged $>18$ years with symptoms of duodenal or gastric ulcer/ gastritis/gastric adenocarcinoma/non-ulcer dyspepsia and no antimicrobial therapy to eradicate $H$. pylori infection. 


\section{Exclusion criteria included}

Previous gastric surgery, any use of bismuth, antimicrobial agents, H2 receptor antagonists, proton-pump inhibitors within 4 weeks before endoscopic examination, or any of several concomitant medical illnesses including cardiac, respiratory, renal, and liver diseases. The study was approved by the institutional ethical committee. All the patients who were enrolled in the study were not exposed to any prior antibiotics for $H$. pylori infection for the previous 2 weeks.

\section{Isolation and identification of $\boldsymbol{H}$. pylori}

Two biopsies were collected from each patient with various GI symptoms, one for rapid urease test and other collected in transport media (Brucella broth + glycerol) were stored in $-80^{\circ} \mathrm{C}$ deep freezer until transportation to Amity University, Noida, for culture. The biopsy samples were transported to Molecular Bacteriology Laboratory at Amity Institute of Biotechnology, Noida, in dry ice. The detail demographic performa of each patient was filled. The biopsies which were in transport media were used for the isolation of $H$. pylori on brain heart infusion agar media (BHIA) Becton Dickinson, Sparks, MD, USA, supplemented with 5\% horse serum; 0.4\% IsovitaleX (Becton Dickinson, Sparks, MD, USA), amphotericin B ( $8 \mu \mathrm{g} / \mathrm{ml})$, trimethoprim $(5 \mu \mathrm{g} / \mathrm{ml})$, and vancomycin $(6 \mu \mathrm{g} / \mathrm{ml})$ and were allowed to incubate at $37^{\circ} \mathrm{C}$ for $3-6$ days under microaerophilic condition $\left(5 \% \mathrm{O}_{2} ; 10 \%\right.$ $\mathrm{CO}_{2} ; 85 \% \mathrm{~N}_{2}$ ) (double gas incubator, Heracell 150i). Identification of the $H$. pylori was on the basis of colony morphology, Gram staining, and observing the positive results of urease, oxidase, and catalase tests. For further use in future, the $H$. pylori suspension was stored in glycerol stock containing BHI broth and $20 \%$ glycerol and were stored at $-80^{\circ} \mathrm{C}$.

\section{DNA extraction and polymerase chain reaction (PCR) amplification} for the confirmation of the $\boldsymbol{H}$. pylori

The bacteria were harvested by colony morphology, and the DNA was extracted by cetyltrimethylammonium bromide method [19] using 24 $\mathrm{h}$ grown confluent lawn of bacterial culture on BHI agar (BHIA, Difco Laboratories) plates.

For molecular confirmation of $H$. pylori colonies, the urease gene was amplified using the primers sequence of UreBF5'-CGTCCGGCAATAGCTGCCATAGT3' and UreBR5'GTAGGTCCTGCTACTGAAGCCTTA3'which gave an amplicon size of $480 \mathrm{bp}$ [20]. The PCR was performed in a final volume of $20 \mu \mathrm{l}$ containing 10X PCR buffer, $500 \mathrm{nM}$ of each primer, $2 \mathrm{mM} \mathrm{MgCl}, 200 \mu \mathrm{M}$ each deoxyribonucleotide triphosphate, $1.5 \mathrm{U}$ Taq DNA polymerase, and 10 ng of DNA sample. PCR was performed in a thermocycler (Eppendorf, Germany) under the following condition; initial denaturation for $2 \mathrm{~min}$ at $96^{\circ} \mathrm{C}$ was followed by 30 cycles of $94^{\circ} \mathrm{C}$ for $30 \mathrm{~s}, 55^{\circ} \mathrm{C}$ for $30 \mathrm{~s}$, and $72^{\circ} \mathrm{C}$ for $40 \mathrm{~s}$. After the final extension of $72^{\circ} \mathrm{C}$ for $10 \mathrm{~min}$, the PCR products were examined by $1 \%$ agarose gel according to the standard procedure. H. pylori strain 26695 was used as a control strain.

\section{Antibiotic susceptibility testing}

The minimum inhibitory concentrations (MICs) for MTZ, FZ, AMX, TET, LEV (Sigma, St Louis, MO, USA), and CLR (Abbott Laboratories, Abbott Park, IL, USA) were determined by agar dilution method as per European Committee on Antimicrobial Susceptibility Testing (EUCAST) guidelines [21]. The positive isolates were considered to be resistant if the MIC was $>8 \mu \mathrm{g} / \mathrm{ml}$ for MTZ, $>0.12 \mu \mathrm{g} / \mathrm{ml}$ for AMX, $>1 \mu \mathrm{g} / \mathrm{ml}$ for TET, $>0.5 \mu \mathrm{g} / \mathrm{ml}$ for CLR, $>2 \mu \mathrm{g} / \mathrm{ml}$ for FZ, and $>1 \mu \mathrm{g} / \mathrm{ml}$ for LEV [21]. For antibiogram profiling, 2-fold serial dilutions of antibiotics were used: MTZ 0.2-64 $\mu \mathrm{g} / \mathrm{ml}$; FZ 0.2-2 $\mu \mathrm{g} / \mathrm{ml}$; AMX 0.12-2 $\mu \mathrm{g} / \mathrm{ml}$; TET 1-4 $\mu \mathrm{g} / \mathrm{ml}$; CLR $0.125-2 \mu \mathrm{g} / \mathrm{ml}$; and LEV $0.2-2 \mu \mathrm{g} / \mathrm{ml}$. H. pylori suspensions were prepared equivalent to McFarland $2\left(1 \times 10^{8} \mathrm{CFU} / \mathrm{ml}\right) .3 \mu \mathrm{l}$ was delivered as a spot on BHIA plates containing different concentrations of antibiotics [22]. Antibiotics free BHIA plates were used as control. All the plates were further incubated under microaerophilic condition at $37^{\circ} \mathrm{C}$ for $72 \mathrm{~h}$ or longer until a visible inhibition ellipse was seen, and the results were interpreted as per EUCAST guidelines [21].
Collection of samples of $B$. capitate

B. capitata was collected from the local Indian market and was further authenticated at the Botany Department of Amity University. The leaves were washed properly and dried in room temperature for 5-10 days. These dried leaves were then grinded into powdered and extracted using methanol, n-hexane, and chloroform.

\section{Preparation of the extract of $B$. capitata}

The extract was prepared in methanol, n-hexane, and chloroform. To prepare the extract about $2 \mathrm{~g}$ of dried powdered plant sample was extracted with $30 \mathrm{ml}$ of methanol, n-hexane, and chloroform consecutively for $72 \mathrm{~h}$ under constant stirring. The extracts were filtered and collected separately, and $30 \mathrm{ml}$ of respective solvent was added to it. The extracts were again filtered and collected after $72 \mathrm{~h}$. The filtered extracts were dried under pressure and suspended in the solvent.

\section{Anti-H. pylori assay of $B$. capitate by disc diffusion assay}

The dual drug-resistant strains of $H$. pylori from Northeast India and multidrug-resistant strains from North India (from our previous study) were included to test the efficacy of n-hexane, methanolic, and chloroform extract of B. capitata. The bacterial colonies were taken directly from the BHIA plate and were suspended in $5 \mathrm{~mL}$ of sterile $0.85 \%$ phosphate buffer saline (PBS). The turbidity of the initial suspension was adjusted by comparing with McFarland's standard number 2 ( $3 \mu \mathrm{l}$ of which contains about $1 \times 10^{8}$ colony-forming units (CFUs) $/ \mathrm{ml}$ ) [23]. Sterile Whatman filter paper disks of $6 \mathrm{~mm}$ in diameter were loaded with different concentration of n-hexane, methanol, and chloroform extracts of B. capitata and placed on the inoculated plates with $3 \times 10^{9} \mathrm{CFU}$ of $H$. pylori. The plates were kept under observation for 2 days at $37^{\circ} \mathrm{C}$ under microaerophilic conditions $\left(5 \% \mathrm{O}_{2}, 10 \% \mathrm{CO}_{2}\right.$, and $\left.85 \% \mathrm{~N}_{2}\right)$. All experiments were performed in triplicates. Pure n-hexane, methanol, and chloroform were used as a negative control and AMX was used as positive control.

\section{Statistical analysis}

Differences between groups were statistically evaluated using the Chi-square test. Differences were considered significant at the $5 \%$ probability level. Statistical analysis was performed using SPSS ver.20 software.

\section{RESULTS}

\section{Isolation of $\boldsymbol{H}$. pylori}

A total of 98 biopsies were collected from the patients within the age group of 18-80 years who were suffering from various GI diseases visiting Gauhati Medical College, Guwahati, Assam. Among the 98 biopsies which were transported to Amity University, Noida; in transport media, H. pylori was successfully isolated from 11 biopsy sample by culture method under microaerophilic condition. All the positive isolates were within the age of $18-80$ years, with $\mathrm{M} / \mathrm{F}$ ratio of 1:0.46.The clinical diagnosis of all the isolates was antral erosion $(n=3)$, antral ulcer $(\mathrm{n}=1)$, conjunctive dystrophy $(\mathrm{n}=1)$, duodenal ulcer $(\mathrm{n}=1)$, and gastritis $(n=5)$.

\section{Identification of the H. pylori}

Rapid urease test (RUT)

The detection of the H. Pylori was done with RUT. H. pylori is urease positive and gives a pink color to the RUT solution $(5 \%$ urea $+2 \%$ phenol red and $\mathrm{P}^{\mathrm{H}}$ 6.6-6.8) indicating the presence of H. pylori.

\section{PCR detection for the confirmation of the $\boldsymbol{H}$. pylori strain}

The DNA of all the 11 isolates was amplified for urease gene using UreBF and $U r e B R$ primers. Analysis was done on $1 \%$ agarose gel confirming the presence of $H$. pylori (Fig. 1).

\section{Antimicrobial susceptibility of the antibiotics}

Agar dilution method was used for determining the MIC of all the antibiotics. Resistance toward MTZ was found in three isolates; MIC $>32 \mu \mathrm{g} / \mathrm{ml}(\mathrm{n}=1), \mathrm{MIC}>16 \mu \mathrm{g} / \mathrm{ml}(\mathrm{n}=1)$, and MIC $>8 \mu \mathrm{g} / \mathrm{ml}(\mathrm{n}=1)$. 
Resistance to LEV founded in $4 / 11$ isolates (MIC $>1 \mu \mathrm{g} / \mathrm{ml}$ ). Of fourresistant strains, three showed dual resistances to MTZ and LEV. All the (11/11) strains were $100 \%$ sensitive toward CLR, TET, AMX, and FZ.

Distribution of antibiotics as per the clinical information

The distribution of MTZ and LEV resistance according to the age, gender, and disease outcome is discussed in Table 1 . As per the association of MTZ and LEV within gender, there was no significant association found.

However, the prevalence of MTZ and LEV resistance was observed more in the patients with the age group of 41-60 years than in the patients with age ranging from 18 to 40 and 61 to 80 years. The MTZ and LEV resistance was seen to be higher in the patients suffering from gastritis, but the association was not significant (Table 1)

All the $11 / 11(100 \%) H$. pylori strains were sensitive toward CLR, TET, AMX, and FZ, and the significant association was found with the gender $(p>0.04)$ and the disease diagnosis $(p \geq 0.004)$, but no significant association was found with patient's age ( $p>0.3$ ) (Fig. 2).

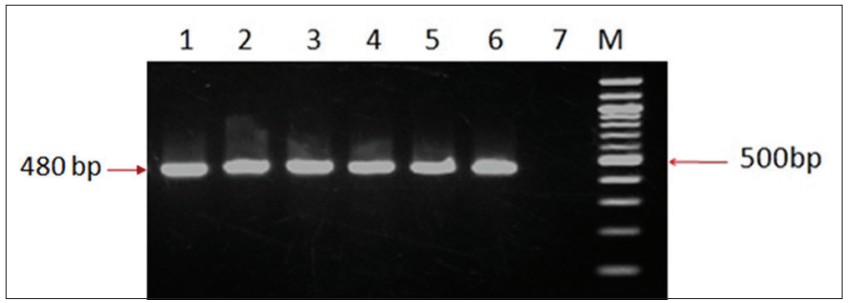

Fig. 1: DNA amplification of urease gene of $480 \mathrm{bp}$ for the confirmation of Helicobacter pylori strains. Lane1- positive control, 26695;Lane 2-6 - H. pylori clinical isolates from Lane 7 - negative control, and Lane M - Marker (100 bp)

Table 1: Correlation between MTZ and LEV susceptibility of $H$. pylori isolates with gender, age, and disease diagnosis

\begin{tabular}{|c|c|c|c|c|}
\hline Clinical information & MTZ (R) & $\mathbf{p}$ & LEV (R) & $\mathbf{p}$ \\
\hline \multicolumn{5}{|l|}{ Gender } \\
\hline Male (n=9) & $3(27 \%)$ & 0.4 & $4(36 \%)$ & 0.36 \\
\hline Female $(n=2)$ & $0(0 \%)$ & & $0(0 \%)$ & \\
\hline \multicolumn{5}{|l|}{ Age } \\
\hline $18-40(n=6)$ & $1(9 \%)$ & 0.4 & $1(9 \%)$ & 2.9 \\
\hline $41-60(n=3)$ & $2(18.1 \%)$ & & $3(27 \%)$ & \\
\hline $61-80(\mathrm{n}=2)$ & $0(0 \%)$ & & $0(0 \%)$ & \\
\hline \multicolumn{5}{|l|}{ Disease diagnosis } \\
\hline Gastritis $(\mathrm{n}=9)$ & $3(27 \%)$ & 4.6 & $\begin{array}{l}4(36 \%) \\
0(0 \%)\end{array}$ & 0.8 \\
\hline $\begin{array}{l}\text { Conjunctive } \\
\text { dystrophy }(\mathrm{n}=1)\end{array}$ & $0(0 \%)$ & & $0(0 \%)$ & \\
\hline Duodenal ulcer (n=1) & $0(0 \%)$ & & $0(0 \%)$ & \\
\hline
\end{tabular}

MTZ: Metronidazole, LEV: Levofloxacin, H. pylori: Helicobacter pylori
Effect of $B$. capitata against the resistant $H$. pylori strains

Two clinical isolates, one from North and other one from Northeast India, were included in the study. Of the two strains, one strain isolated from North Indian patient was multidrug resistant showing resistance toward MTZ, CLR, and LEV and the other from Northeast India was dual drug resistant showing resistance toward MTZ and LEV.

Different concentration of n-hexane, methanol, and chloroform extract was loaded on the disc and was air dried. $100 \mathrm{ul}$ of the H. pylori strains dissolved in PBS having McFarland $2(3 \times 109 \mathrm{CFU} / \mathrm{ml})$ was spread on the BHI plate. The disc loaded with the extracts was placed upside down on the H. pylori plates. After $72 \mathrm{~h}$ of incubation under microaerophilic condition, we found that the n-hexane, methanolic, and chloroform extract of B. capitata showed anti-H. pylori activity on both dual and multidrug-resistant strains (Table 2). The MIC for multidrug-resistant strain of North India was $100 \mu \mathrm{g}$ for n-hexane, $20 \mu \mathrm{g}$ for methanol, and $10 \mu \mathrm{g}$ for chloroform extracts. The diameter of zone of inhibition was found to be $8 \mathrm{~mm}, 6 \mathrm{~mm}$ for n-hexane, $7 \mathrm{~mm}$ for methanol, and $6 \mathrm{~mm}$ and $8 \mathrm{~mm}$ for chloroform extracts of B. capitata, respectively, for North and Northeast strains.

The MIC and the diameter of the zone of inhibition for dual drugresistant strain of Northeast India and multidrug-resistant strains of North India were similar when tested against various extracts of B. capitata (Fig. 3).

\section{DISCUSSION}

H. pylori infection causes several GI diseases in both developing and industrialized country and has direct impact on health-care system worldwide [24]. Eradication of H. pylori with a proton-pump inhibitor-based triple therapy is presently used to treat $H$. pylori infection [21]. Although it has a success rate of $80-90 \%$, problems such as treatment failure and contraindications for some patients are common. Furthermore, rapidly emerging drug resistance in $H$. pylori strains during treatment with various antibiotics is a major obstacle for successful eradication therapies [1]. Due to the prevalence of antibioticresistant $H$. pylori strains, there is an increasing search for safe and effective non-antibiotic compounds that inhibit $H$. pylori growth. In the Indian traditional medical system, a number of plants and plant products are known to possess potent medicinal properties, suggesting their usefulness in treatment.

Antibiotics, namely MTZ, CLR, and TET are the major drugs used for the treatment of several different types of infections including the H. pylori infection [25] which could be the reason for the high level of antibiotic resistance from mainly MTZ in many parts of India. Northern India such as Delhi and Chandigarh has reported a lower prevalence of resistant strains, i.e. $37.5 \%$ and $38.2 \%$, respectively [26]. Eastern India observes high MTZ resistance with 85\% [27] along with South India which includes Hyderabad and Chennai having $100 \%$ and $88.2 \%$, respectively [28]. The MTZ resistance of $H$. pylori may be because of the extensive use of this inexpensive antibiotic for the treatment of parasitic, genital, and dental infections, especially in developing countries [29].

Table 2: Antimicrobial activity of $\mathbf{n}$-hexane, methanolic, and chloroform extract of $B$. capitata against the dual and multidrug-resistant strains of North Indian (strain1) and Northeast India (strain 2)

\begin{tabular}{|c|c|c|c|c|c|c|c|}
\hline \multirow[t]{2}{*}{ Strain nos. } & \multirow[t]{2}{*}{$\begin{array}{l}\text { MIC for MTZ, CLR, LEV } \\
\text { (agar dilution method) }\end{array}$} & \multicolumn{2}{|c|}{$\begin{array}{l}\mathrm{n} \text {-hexane extract of } \\
\text { B. capitate (disc diffusion assay) }\end{array}$} & \multicolumn{2}{|c|}{$\begin{array}{l}\text { Methanolic extract of } \\
\text { B. capitata (disc diffusion assay) }\end{array}$} & \multicolumn{2}{|c|}{$\begin{array}{l}\text { Chloroform extract of } \\
\text { B. capitata (disc diffusion assay) }\end{array}$} \\
\hline & & $\begin{array}{l}\text { Amount } \\
\text { (in } \mu \mathrm{g} \text { ) }\end{array}$ & $\begin{array}{l}\text { Zone of inhibition } \\
\text { (in } \mathrm{mm} \text { ) }\end{array}$ & $\begin{array}{l}\text { Amount } \\
\text { (in } \mu g \text { ) }\end{array}$ & $\begin{array}{l}\text { Zone of inhibition } \\
\text { (in } \mathrm{mm} \text { ) }\end{array}$ & $\begin{array}{l}\text { Amount } \\
\text { (in } \mu g \text { ) }\end{array}$ & $\begin{array}{l}\text { Zone of inhibition } \\
\text { (in } \mathrm{mm} \text { ) }\end{array}$ \\
\hline Strain 1 & $\begin{array}{l}\mathrm{MTZ}=64 \mu \mathrm{g} / \mathrm{ml} \\
\mathrm{CLR}=4 \mu \mathrm{g} / \mathrm{ml} \\
\mathrm{LEV}=2 \mu \mathrm{g} / \mathrm{ml}\end{array}$ & 100 & 8 & 20 & 7 & 10 & 6 \\
\hline Strain 2 & $\begin{array}{l}\mathrm{MTZ}=32 \mu \mathrm{g} / \mathrm{ml} \\
\mathrm{LEV}=1 \mu \mathrm{g} / \mathrm{ml}\end{array}$ & 100 & 6 & 20 & 7 & 10 & 8 \\
\hline
\end{tabular}

B. capitata: Brassica capitata, MIC: Minimum inhibitory concentration, MTZ: Metronidazole, LEV: Levofloxacin, CLR: Clarithromycin 


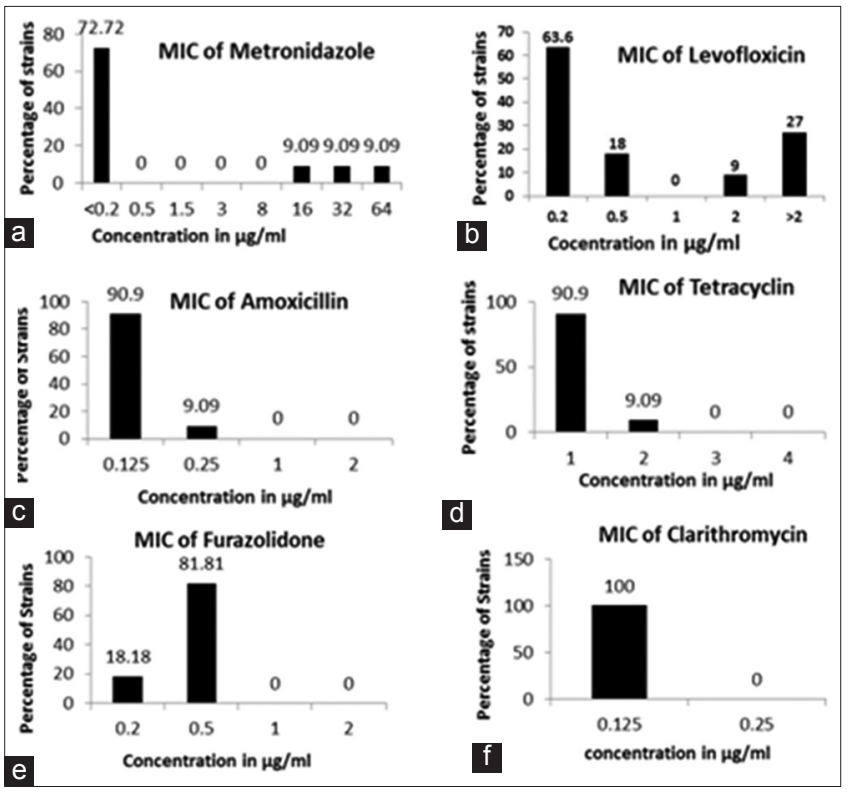

Fig. 2: Distribution of minimum inhibitory concentration of antibiotics among the Helicobacter pylori strains isolated from Northeast India. Metronidazole (a), levofloxacin (b), amoxicillin (c), tetracycline (d), furazolidone (e), and clarithromycin (f)

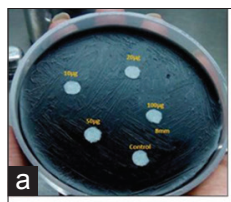

n-Hexane extract of $B$. capitata

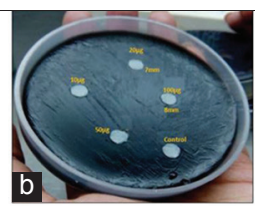

Methanol extract of $B$. capitata

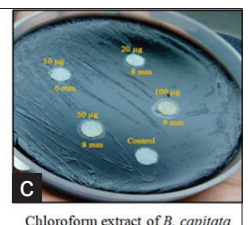

Chloroform extract of $B$. capitata
Fig. 3: Disc diffusion method: Antimicrobial activity of Brassica capitata against the drug resistance strains of Helicobacter pylori (a) n-hexane extract (b) methanolic extract (c) chloroform extract

Studies comprehend that the resistance is due to inactivation of gene $r d x A$ and frx gene [30,31].

Another drug of choice for the treatment is CLR that is commonly used in the triple therapy for the eradication of $H$. pylori having an efficacy of $90 \%$ [32]. The level of resistance for CLR varies in India, namely Lucknow (82\%), Mumbai (91\%), Hyderabad (96\%) [28], Kolkata (0\%) [30], Gujarat (58.8\%) [33], and Delhi (11.8\%) [34]. Studies have shown that the CLR resistance is due to the mutation in the 23S rRNA gene at $2142(\mathrm{~A}-\mathrm{G}), 2143(\mathrm{~A}-\mathrm{G})$, and $2182(\mathrm{~T}-\mathrm{C})$ positions [34].

LEV can also be an option as a drug for the eradication of H.pylori as has been reported in many countries. According to the recommended guidelines, if the LEV resistance in the susceptibility test of $H$. pylori is over $20 \%$, then the antibiotic is not considered as a good option. Its resistance rate in Gujarat is 13.8\% [33] and in North India is 73.2\% [35].

Our study reports on the antibiotic sensitivity pattern toward AMX, TET, CLR, and FZ of all the 11 Northeast strains isolated from Guwahati, Assam. We found that all the 11 strains were sensitive toward the AMX, TET, CLR, MTZ, LEV and FZ. It has been observed that $27 \%$ of the $H$. pylori strains showed resistance toward MTZ, 36.3\% of the strains toward LEV and rest $27 \%$ toward both MTZ and LEV.

Due to increase use of antibiotics over the last two decades, H. pylori has acquired the antibiotic resistance which is one of the main causes of treatment failure. De et al. have mentioned the anti-H. pylori effect of curcumin and their use in the treatment of the H. pylori infection [36]. In our previous study, we have reported the efficacy of Emblica officinalis [37], Paedra foetida [38], and Parmelia perlata [39] against the drug-resistant $H$. pylori strains. B. capitata which is leafy vegetable and is used in cooking with the nutritive value being rich in calcium and protein, and Vitamin C is utilized for healing process [40,41]. This prompted us to explore its antimicrobial potential against multi and dual drug-resistant strains of North and Northeast India. The n-hexane, methanolic, and chloroform extract of B. capitata were tested by disc diffusion method for its efficacy against $H$. pylori. Zone of inhibition with the n-hexane extract for North Indian and Northeast strains at MIC of $100 \mu \mathrm{g}$ was $8 \mathrm{~mm}$ and $6 \mathrm{~mm}$, respectively. The methanol extract showed $7 \mathrm{~mm}$ zone for both the strains at MIC of $20 \mu \mathrm{g}$ and chloroform extract showed the best effect at the MIC of $10 \mu \mathrm{g}$ with $6 \mathrm{~mm}$ of zone of inhibition for North Indian strain and $8 \mathrm{~mm}$ zone of inhibition for Northeast strains.

Overall, this study provides novel insights into the therapeutic potential of $B$. capitata against $H$. pylori infections, although further studies are required to extrapolate its effect on humans.

\section{CONCLUSION}

Our study highlights the potential antibacterial activity of B. capitata against $H$. pylori in vitro irrespective of the genetic makeup of the strains. However, its MIC is relatively high which may be due to the poor bioavailability of $B$. capitata extracts. Furthermore, our study for the $1^{\text {st }}$ time in India studied the Northeast Indian strains which were found to be sensitive to most of the antibiotics used for the treatment regime, whereas other parts of India reported high multidrug resistance [29].

\section{ACKNOWLEDGMENT}

We thank Amity University for providing the infrastructure and support to carry out the work.

\section{AUTHOR'S CONTRIBUTION}

$\mathrm{RD}$ and KD have given the concept of antibiogram profiling of $H$. pylori strains of Northeast India. RD and AKM have finalized the manuscript. SM has performed the experiments, analyzed the data, and drafted the manuscript. SB has provided the $B$. capitate sample and finalized the manuscript. VG and MR have performed some of the experiments. SD and AKA have provided the samples and analyzed the clinical data.

\section{CONFLICTS OF INTEREST}

The authors declare that they have no conflicts of interest.

\section{FUNDING}

This study was supported by the Department of Biotechnology (DBT) grant no. (BT/240/NE/TBP/2011) and Department of Science and Technology (DST) grant no. (SR/FP/LS/118/2008). SM is an Assistant Professor-II and supported by Amity University, Noida

\section{REFERENCES}

1. Blasér MJ. Ecology of Helicobacter pylori in human stomach. J Clin Invest 1997;100:759-62.

2. De Luca A, Iaquinto G. Helicobacter pylori and gastric diseases: A dangerous association. Cancer Lett 2004;213:1-10.

3. Ahn HJ, Lee DS. Helicobacter pylori in gastric carcinogenesis. World J Gastrointest Oncol 2015;7:455-65

4. Fallahi GH, Maleknejad S. Helicobacter pylori culture and antimicrobial resistance in Iran. Indian J Pediatr 2007;74:127-30.

5. Dzierzanowska-Fangrat K, Rozynek E, Celinska-Cedro D, Jarosz M, Pawlowska J, Szadkowski A. Antimicrobial resistance of Helicobacter pylori in Poland: A multicentre study. Int $\mathrm{J}$ Antimicrob Agents 2005;26:230-4.

6. Poddar U, Yachha SK. Helicobacter pylori in children: An Indian perspective. Indian Pediatr 2007;44:761-70

7. Phukan RK, Narain K, Zomavia E. Dietry habits and stomach cancer in Mizoram, India. J Gastroenterol 2006;41:418-24.

8. Hoffman JS, Cave DR. Treatment of Helicobacter pylori. Curr Opin Gastroenterol 2001;17:30-4. 
9. Broutet N, Tchamgoue S, Pereira E, Lamouliatte H, Salamon R, Megraud F. Risk factors for failure of Helicobacter pylori therapyresults of an individual data analysis of 2751 patients. Aliment Pharmacol Ther 2003;17:99-109.

10. Nahar S, Mukhopadhyay AK, Khan R, Ahmad MM, Datta S, Chattopadhyay S. Antimicrobial susceptibility of Helicobacter pylori strains isolated from Bangladesh. J Clin Microbiol 2004;42:4856-8, 290.

11. Debets-Ossenkopp YJ, Herscheid AJ, Pot RG, Kuipers EJ, Kusters JG, Vandenbroucke-Grauls CM. Prevalence of Helicobacter pylori resistance to metronidazole, clarithromycin, amoxicillin, tetracycline and levofloxacin in the Netherlands. J Antimicrob Chemother 1999; 43:511-5, 294

12. Toracchio S, Cellini L, Campli ED, Cappello G, Malatesta MG, Ferri A. Role of antimicrobial susceptibility testing on efficacy of triple therapy in Helicobacter pylori eradication. Aliment Pharmacol Ther 2000;4:1639-43.

13. Godoy AP, Ribeiro ML, Benvengo YH, Vitiello L, Miranda Mde C, Mendonca S. Analysis of antimicrobial susceptibility and virulence factors in Helicobacterpylori clinical isolates. BMC Gastroenterol 2003;3:20.

14. Siavoshi F, Pourkhajeh AH, Merat SH, Asl-Soleimani H, Heydarian E, Khatibian M. Susceptibility of various strains of $H$. pylori to selected agents. Arch Iran Med 2000;3:60-3.

15. Sharara AI, Chedid M, Araj GF, Barada KA, Mourad FH. Prevalence of Helicobacter pylori resistance to metronidazole, clarithromycin, amoxicillin and tetracycline in Lebanon. Int $\mathrm{J}$ Antimicrob Agents 2002; $19: 155-8$

16. Glupczynski Y, Megraud F, Lopez-Brea M, Andersen LP. European multicenter survey of in vitro antimicrobial resistance in Helicobacter pylori. Eur J Clin Microbiol Infect Dis 2001;20:820-3.

17. Joo YE. Natural product-derived drugs for the treatment of inflammatory bowel diseases. Intestinal Res 2014;12:103-9.

18. Uh M, Kassie F, Rabot S, Grasl-Kraupp B, Chakraborty A, Laky B, et al. Effect of common Brassica vegetables (Brussels sprouts and Red cabbage) on the development of preneoplastic lesions induced by 2-amino-3- methylimidazo [4,5-f] quinoline (IQ) in liver and colon of Fischer 344 rats. J Chromatogr B Anal Technol Biomed Life Sci 2004;802:225-30.

19. Murray MG, Thompson WF. Rapid isolation of high molecular weight plant DNA. Nucleic Acid Res 1980;8:4321-5.

20. Chattopadhyay S, Patra R, Ramamurthy T, Chowdhury A, Santra A, Dhali GK. Multiplex PCR assay for rapid detection and genotyping of Helicobacter pylori directly from biopsy specimens. J Clinn Microbiol 2004:42:2821-4

21. EUCAST. Breakpoint Tables for Interpretation of MICs and Zone Diameters. Version3.1; 2013.

22. Fourth Informational Supplement M100-S14. National Committee for Clinical Laboratory Standards, Performance Standards for Antimicrobial Susceptibility Testing. Wayne, PA: NCCLS; 2004

23. Clinical Laboratory Standard Institute. Methods for Antimicrobial Dilution and Disk Susceptibility Testing of Infrequently Isolated or Fastidious Bacteria; Approved guideline- Second edition. CLSI document M45-A2, Vol. 30. Wayne, PA, USA: CLSI; 2010.

24. Dunn BE, Cohen H, Blaser MJ. Helicobacter pylori. Clin Microbiol Rev 1997;10:720-41.
25. Bindayna KM. Antibiotic susceptibilities of Helicobacter pylori. Saudi Med J 2001;22:53-7.

26. Singh V, Mishra S, Maurya P, Rao G, Jain AK, Dixit VK, et al. Drug resistance pattern 324 and clonality in H. pylori strains. J Infect Dev Ctries 2009;3:130-6.

27. Datta S, Chattopadhyay S, Patra R, De R, Ramamurthy T, Hembram J. Most Helicobacter pylori strains of Kolkata in India are resistant to MTZ but susceptible to other drugs commonly used for eradication and ulcer therapy. Aliment Pharmacol Ther 2005;22:51-7.

28. Thyagarajan SP, Ray P, Das BK, Ayyagari A, Khan AA, Dharmalingam S, et al. Geographical difference in antimicrobial resistance pattern of Helicobacter pylori clinical isolates from Indian patients: Multicentric study. J Gastroenterol Hepatol 2003;18:1373-22, 8 .

29. Vakil N, Megraud F. Eradication therapy for Helicobacter pylori. Gastroenterology 2007;133:985-1001.

30. Marais A, Bilardi C, Cantet F, Mendz GL, Mégraud F. Characterization of the genes $r d x A$ and frx $A$ involved in metronidazole resistance in Helicobacter pylori. Res Microbiol 2003;154:137-44.

31. Gehlot V, Mahant S, Mukhopadhyay AK, Das K, De R, Kar P, et al. Antimicrobial susceptibility profiles of Helicobacter pylori isolated from the patients in North India. J Glob Antimicrob Resist 2015;5:51-6.

32. Bazzoli F, Zagari RM, Fossi S, Pozzato P, Roda A, Roda E. Efficacy and tolerability of a short-term low-dose triple therapy for eradication of Helicobacter pylori. Gastroenterology 1993;104:40A.

33. Pandya HB, Agravat HH, Patel JS, Sodagar NR. Emerging antimicrobial resistance pattern of Helicobacter pylori in central Gujarat. Indian J Med Microbiol 2014;32:408-13.

34. Gehlot V, Mahant S, Mukhopadhyay AK, Das K, Alam J, Ghosh P, et al. Low prevalence of clarithromycin-resistant Helicobacter pylori isolates with A2143G point mutation in the $23 \mathrm{~S}$ rRNA gene in North India. J Glob Antimicrob Resist 2016;6:39-43.

35. Gehlot V, Mahant S, Das R. Most of the Helicobacter pylori isolates are resistant to levofloxacin in North India. Int J Pharm Pharm Sci 2016;8:454-6.

36. De R, Kundu P, Swarnakar S, Ramamurthy T, Chowdhury A, Nair GB, et al. Antimicrobial activity of curcumin against Helicobacter pylori isolates from India and during infections in mice. Antimicrob Agents Chemother 2009;53:1592-7.

37. Mehrotra S, Jamwal R, Shyam R, Meena DK, Mishra K, Patra R, et al. Anti-Helicobacter pylori and antioxidant properties of Emblica officinalis pulp extract: A potential source for therapeutic use against gastric ulcer. J Med Plants Res 2011;5:2577-83.

38. Chanda S, Gehlot V, Das R, Mahant S, Das K, Singh K, et al.Antimicrobial activity of herbal extract against drug resistant Helicobacter pylori isolates from India. World J Pharm Res 2014;3:1234-43.

39. Gehlot V, Mahant S, VijayraghwanP, Das K, Hoda S, Das R. Therapeutic potential of lichen Parmelia perlata against dual drug-resistant Helicobacter pylori isolates. Int J Pharm Pharm Sci 2016;8:205-8.

40. Carvalho CA, Silva MB, Oliveira TG, Lima JM, Rosa MB. Spectrometric study at different phenologic stages of the cabbage (Brassica oleraceaevar. capitata). Rev Bras Farm 2008;18:249-57.

41. Silva Jr AA, Miura L, Yokoyama S. Cabbage: New summer cultivars. Agrop Catarinense 1988;1(3):47-9. 